\title{
AUTHORS' OWN METHOD OF DIATHERMIC THERMAL ABLATION OF VENOUS PERFORATORS - SURGERY WITH PROTECTIVE TUMESCENCE
}

\author{
Roman Sławomir Kuśnierczyk', Przemysław Nowakowski² \\ ${ }^{1}$ General Surgical Department, Scanmed St. Raphael's Hospital in Krakow, Poland \\ 2PAKS American Heart of Poland - Malopolska Cardiovascular Centre, Vascular Surgery \\ Department, Poland
}

\begin{abstract}
Objectives: Low-invasive endovenous thermal ablation techniques have become the preferred modality for the treatment of incompetent perforating veins.

Material and methods: We managed 210 varicose-vein patients (268 limbs) presenting with coexisting superficial and perforator incompetence. We utilised bipolar radiofrequency ablation for the treatment of incompetent superficial veins and monopolar diathermal ablation under protective tumescence to manage incompetent perforators. To ablate incompetent perforating veins with monopolar diathermy we used a modified peripheral intravenous catheter with a long needle for administration of tumescence.

Results: The success rate of thermal ablation of incompetent perforating veins, defined as completely occluded perforators demonstrated by Doppler sonography at one-year follow-up, was $95 \%$. A similarly defined success rate of radiofrequency closure of incompetent superficial veins was $97 \%$. There were no serious intraoperative complications such as deep vein thrombosis, peripheral nerve injuries, skin burns or persistent hyperpigmentations. There were transient hypoesthesias in $20 \%$ of patients presenting with incompetent Cockett I and Cockett II perforators. In addition, 96\% of patients presenting with active ulcers had their ulcers healed 30-60 days after the procedure.

Conclusions: Monopolar diathermy with the use of protective tumescence enables minimally invasive, effective, and precise ablation of incompetent perforators. This method is also safe, with no associated injury to adjacent anatomical structures or thromboembolic complications.
\end{abstract}

Key words: venous ulcer, venous perforators, endovenous/endothermal ablation.

\author{
ORIGINAL PAPER \\ Phlebological Review 2016; 24, 4: 60-65 \\ DOl: https://doi.org/10.5114/pr.2016.67743
}

Submitted: 21.11 .2016

Accepted: 24.03.2017

\section{Address for correspondence}

Roman Sławomir Kuśnierczyk

Scanmed St. Raphael's Hospital in Krakow

General Surgical Department

ul. Adama Bochenka 12

30-693 Krakow, Poland

e-mail: kusnierczyk@poczta.onet.pl

\section{INTRODUCTION}

Chronic venous insufficiency of the lower limbs is often caused by incompetence of the valves of superficial and perforating veins, which results in impaired venous outflow from limbs towards the heart $[1,2]$. In order to manage venous insufficiency effectively it is necessary to ablate all incompetent superficial veins, as well as incompetent perforators $[3,4]$. Currently, low-invasive endovenous thermal ablation techniques have become the preferred treatment modality for this purpose [5-7], not only because of low invasiveness of such a procedure, but also due to the possibility of conducting the treatment in an outpatient basis. Importantly, the use of intraoperative sonography improves efficacy and safety of treatment. In this paper we describe our own technique for endovascular thermal ablation of incompetent veins and the results of such a modified management. We performed bipolar radio-frequency induced thermal ablation of incompetent superficial veins and monopolar diathermal ablation under protective tumescence with $0.9 \%$ sodium chloride for the closure of incompetent perforators.

\section{MATERIAL AND METHODS}

We analysed the results of treatment of 210 consecutive patients who were managed between December 2011 and December 2015. These patients presented with class C3 to C6 according to the CEAP classification. Ninety-seven of the patients received treatment on both sides, thus in total we managed 307 lower limbs with varicose veins, including 268 limbs with coexisting superficial and perforator incompetence. In this particular group of patients we utilised two different techniques to ablate 
incompetent veins: bipolar radio-frequency-induced thermotherapy (RFITT) with the use of the Celon system (Olympus, Center Valley, PA, USA) $[8,9]$ for the closure of incompetent saphenous or other large superficial veins, while in order to close incompetent perforators we utilised monopolar diathermal ablation (MDA) with the Eltron 160 (Bechtold \& Co., Łódź, Poland) under protective tumescence with $0.9 \%$ sodium chloride. In total, we ablated 307 incompetent perforators. Characteristics of patients and localisation of incompetent superficial veins are given in Table 1.

All patients were treated on an outpatient basis, and the procedures were carried out under spinal anaesthesia. Preoperative screening for perforator incompetence comprised Doppler sonography. Nevertheless, the final decision of the closure of such an incompetent perforator depended on intraoperative Doppler sonography, which was performed in the supine body position after endovenous ablation of incompetent superficial veins. A reflux provoked by Valsalva manoeuvre after successful clo- sure of incompetent superficial veins was an indication for thermal ablation of such a perforator. In addition, we managed all perforators with preoperative diameter in the standing position more than $4 \mathrm{~mm}$. Details regarding localisation of incompetent perforators managed with MDA are given in Table 2. There were two main indications to perform MDA under protective tumescence: in group 1 perforating veins comprising Cockett's, Bassey's, and Thiery's perforators this was due to anatomical location of such veins and risk of injury to adjacent arteries, deep veins, and nerves; in group 2 comprising May's and Hunter's perforators an unusual anatomy of the vein posing a risk of postprocedural deep venous thrombosis was an indication to perform ablation under protective tumescence. Diameters of incompetent perforators positioned at the level of the fascia in the standing position in group 1 ranged from 4 to $8 \mathrm{~mm}$, and in group 2 perforators in the same body position their diameters ranged from 4 to $20 \mathrm{~mm}$. Our method of closure of incompetent perforators comprised insertion of a catheter into the target vein

Table 1. Localisation of incompetent superficial veins ablated with radiofrequency-induced thermotherapy (in some patients both legs and/or more than one vein were managed); GSV - great saphenous vein; SSV - small saphenous vein; AASV - anterior accessory saphenous vein; $\mathrm{G}$ - Giacomini vein; $\mathrm{L}$ - Leonardo's vein (the posterior arch vein); $M$ - more than one vein ablated; C4 or 5 , C6 - according to CEAP classification

\begin{tabular}{c|c|c|c|c|}
\hline Number of patients & CSV or 5 \\
\hline Females & & Recurrent varicose \\
veins
\end{tabular}

Table 2. Localisation of incompetent superficial veins managed with monopolar diathermal ablation

\begin{tabular}{|c|c|c|c|c|c|c|}
\hline \multirow[t]{2}{*}{ Patients } & \multirow[t]{2}{*}{ Number } & \multicolumn{4}{|c|}{ Group I perforators } & \multirow{2}{*}{$\begin{array}{l}\text { Group II perforators } \\
\text { (May's, Hunter's) }\end{array}$} \\
\hline & & Cockett I & Cockett II & Bassey's & Thiery's & \\
\hline Females & 144 & 35 & 133 & 24 & 4 & 10 \\
\hline Males & 66 & 25 & 53 & 12 & 1 & 10 \\
\hline Total & 210 & 60 & 186 & 36 & 5 & 20 \\
\hline
\end{tabular}




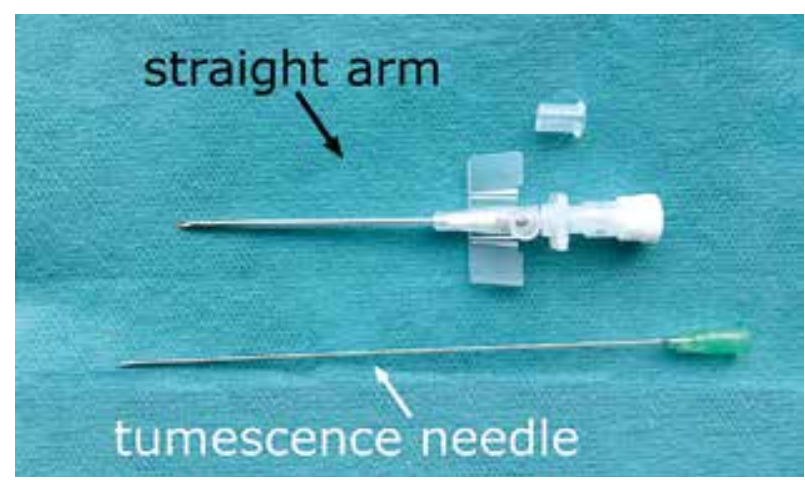

Fig. 1. Armamentarium used for monopolar diathermal ablation with protective tumescence

and thermal ablation by launching the monopolar mode of the Eltron 160 set using a frequency of $600 \mathrm{kHz}$ and power of $60 \mathrm{~W}$. The duration of ablation depended on the intraprocedural sonographic appearance of the perforator. A properly ablated vein rapidly constricted, became hyperechogenic and incompressible. After the procedure the patients were advised to wear compression stockings of working pressure $34-46 \mathrm{mmHg}$ for two weeks. Patients were advised not to remove the stockings for the first seven postoperative days, except for those presenting with venous ulcers, if dressing changes were necessary. Follow-up Doppler sonographies were performed 7 and 30 days after the surgery, and every year thereafter. The duration of follow-ups of patients who underwent combined RFITT and MDA treatments was 10-58 months.

\section{ARMAMENTARIUM USED FOR MDA UNDER PROTECTIVE TUMESCENCE}

We used a $16 \mathrm{G}$ peripheral intravenous catheter and a long $21 \mathrm{G}$ tumescent needle (Fig. 1). The intravenous catheter, acting as a straight arm, should be modified in order to increase the length of needle with which the thermal ablation is performed. For this purpose, the catheter should be disassembled and the plastic ring at its base removed. Reassembly of the catheter makes the needle longer than its plastic sheath. This plastic sheath of the intravenous catheter serves the purpose of insulating adjacent tissues from electric current and thermal injury. The tumescent needle should be long enough and of suitable diameter to make possible the administration of tumescence fluid through the above-described modified intravenous catheter (Fig. 2). Thus our modified instrument for the closure of perforating veins consisted of an introducer sheath, diathermic ablation applicator, and a needle for administration of tumescence, all in one device. This tool can be operable with one hand, and the whole procedure be performed by one surgeon who guides the procedure with Doppler sonography, holding the sonographic probe with the other hand.

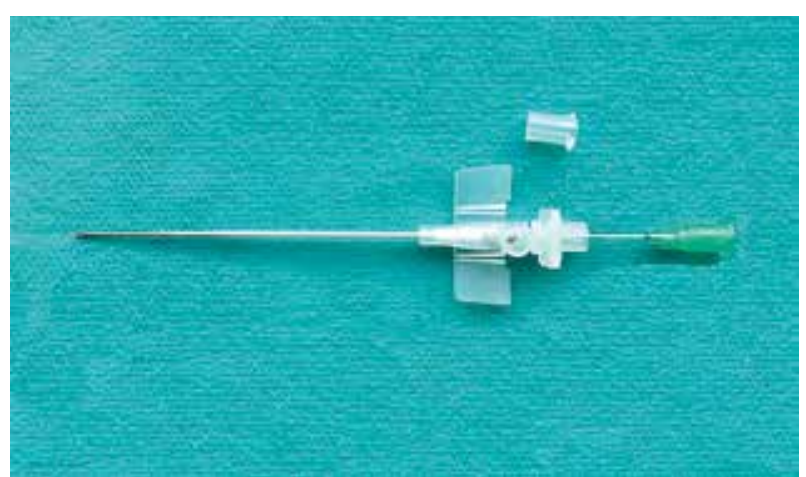

Fig. 2. Tumescence needle inside the modified intravenous catheter

Technical details of the procedure are presented at: https://medtube.net/vascular-surgery/medical-videos/ 13086-the-own-method-of-diathermic-thermal-ablationof-perforating-veins-and-varicose and https://medtube. net/vascular-surgery/medical-videos/16339-ownmethod-of-performing-diathermic-thermal-ablation-ofperforators-with-protective-tumescence.

The whole procedure, under sonographic guidance, should be performed in the following steps:

- intravenous catheter, without tumescent needle inside, is inserted into the target perforator at the level of the fascia or below the fascia;

- the intravenous catheter, with its tip still inside the perforating vein, is placed obliquely to the perforator wall, the tumescent needle is inserted into the intravenous catheter, and its tip is located outside the perforating vein, in the subfascial space;

- a small volume of tumescence is administered to the subfascial space (pre-tumescence), which results in separation of blood vessels and nerves, and also in constriction of the dilated perforator and its tributaries;

- with the use of MDA, thermal ablation of subfascial part of the perforator is performed and then more tumescence fluid is administered (post-tumescence);

- with the tumescence needle withdrawn, the tip of the intravenous catheter is located above the fascia and thermal ablation of the epifascial part of the perforator is performed;

- all connections between the incompetent perforator and the incompetent superficial veins are also managed with MDA; in the case of atrophic changes of the skin and/or subcutaneous tissue in the area of such veins, a pre-tumescence is administered, similarly to the management of a perforating vein, and in the case of normal skin only post-tumescence is applied.

Importantly, all these steps should be performed smoothly, without unnecessary manoeuvres that might result in undesired relocation of the device outside the target vein. Of note, in patients presenting with class C4-6 of the CEAP classification [10-12] for technical reasons 
Table 3. Postoperative complications associated with ablation of incompetent perforating veins (numbers of ablated perforators are given in brackets)

\begin{tabular}{lccccc}
\hline Adverse event & \multicolumn{3}{c}{ Group I perforators } & Group II perforators: \\
\cline { 2 - 5 } & Cockett I (60) & Cockett II (186) & Bassey's (36) & Thiery's (5) & May's, Hunter's (20) \\
\hline Transient nerve injury & 14 & 44 & 0 & 0 & 0 \\
\hline Permanent nerve injury & 0 & 0 & 0 & 0 & 0 \\
\hline Deep vein thrombosis & 0 & 0 & 0 & 0 & 0 \\
\hline Artery injuries, haematoma & 0 & 0 & 0 & 0 & 0 \\
\hline Recanalisation of ablated perforator & 3 & 8 & 2 & 0 & 0 \\
\hline
\end{tabular}

Table 4. Patients presenting with advanced venous disease: grade C4-C6 according to the CEAP classification; N/A - not applicable

\begin{tabular}{ccccc}
\hline CEAP & Number of patients & Ulcer healed & Ulcer healed & $\begin{array}{c}\text { No progression according to C parameter of the } \\
\text { CEAP classification }\end{array}$ \\
\hline C4-5 & 30 & N/A & N/A & 30 \\
\hline C6 & 26 & 25 & 1 & N/A \\
\hline
\end{tabular}

and because of the risk of exacerbation of tissue damage, we did not manage the epifascial part of incompetent perforators and ablated only subfascial portions of these incompetent veins.

\section{RESULTS}

The success rate of thermal ablation of incompetent perforating veins, defined as completely occluded perforators demonstrated by Doppler sonography at follow ups seven and 30 days, and one year after the procedure was $95 \%$. A similarly defined success rate of RFITT for incompetent superficial veins was $97 \%$. There were seven patients with still incompetent great saphenous veins and one patient with incompetent small saphenous vein despite RFITT ablation. There were also 13 patients with recanalised perforators, but these veins were of small diameter and without pathological reflux revealed by Doppler sonography (Table 3), and there were no recurrent varicosities in the area of such recanalised veins.

We did not observe serious intraoperative or postoperative complications. Neither deep vein thrombosis, peripheral nerve injuries, skin burns, nor persistent hyperpigmentations were diagnosed at follow-ups. Some hyposthenic patients developed transient indurations of subcutaneous tissue and transient hyperpigmentations in the area of MDA, which were similar to such reactions following RFITT of superficial veins. These skin problems were of moderate intensity, were managed with local nonsteroidal anti-inflammatory drugs, and persisted for seven days maximally. Hypoesthesia in the area of the medial malleolus was reported by $20 \%$ of patients managed for incompetent Cockett I or II perforators. These neurologic adverse events completely resolved between 30 and 90 days after the procedure (Table 3). Out of 26 patients presenting with active ulcers, 25 of them (96\%) were free of ulceration at follow-up one year after the treatment. Duration of healing of an ulcer after the procedure was 30-60 days. The ulcer area in the remaining patient decreased by $50 \%$. In addition, at one-year follow-up there were no progressions of skin changes in patients presenting with class C4 and C5 (Table 4).

\section{DISCUSSION}

Incompetent perforators constitute one of the components of chronic venous disease [13-16]. Even if their clinical meaning is still under debate [17-19], their closure in patients presenting with severe venous insufficiency, such as class C5 and C6 according to the CEAP classification, significantly contributes to better results of treatment [20-28]. Incompetence of perforating veins can be of primary or secondary nature. In the latter case (the so-called re-entry perforators), once an overload in the superficial system is eliminated, a proper function of the perforating vein can be restored. Nevertheless, it remains unclear whether an incompetent perforator should be ablated or can be managed conservatively and the treatment should comprise only closure of incompetent superficial veins. It has also been reported that ablation of incompetent perforators in patients presenting with class C3-4 is associated with disappearance of varicosities connected to these veins. Currently, incompetent perforators are preferentially managed using minimally invasive techniques [29], such as RF and laser thermal ablations $[30,31]$, foam sclerotherapy, and closure with cyanoac- 
rylate glue [32]. Except for foam sclerotherapy, ablation of perforators with other methods is performed through an introducer (a sheath or a needle). The target perforator usually runs perpendicularly or obliquely to the skin surface, and therefore its section eligible for inserting the introducer is no longer than $2-3 \mathrm{~cm}$. Therefore, an insertion of the introducer can be challenging and carries the risk of positioning of the intravascular device outside the vein, with possible extravascular injuries. A solution to this problem can be the use of perforator-dedicated devices, for example ClosureRFS ${ }^{\mathrm{m}}$ Stylet (Covidien, Hampshire, UK) [33]. However, an additional RF introducer significantly increases the total cost of procedure. A use of normal needles as introducers for laser ablation of perforators is associated with a risk of burns when the tip of the laser touches the needle. Closure of perforators with glue is extremely challenging if such a vein is short, but this method is highly effective and painless. Ultrasound-guided foam sclerotherapy is a commonly used and accepted method, but its efficacy is statistically worse than other treatments [34].

Thermal ablation of the veins using monopolar diathermy occludes the vessel along its long axis, and according to our own experience such an occlusion extends 1 $\mathrm{cm}$ in each direction from the tip of the device. The efficacy of MDA was assessed intraoperatively, using the above-described sonographic features of successful ablation, and with the same diagnostic modality at follow ups $[35,36]$. In contrast to foam sclerotherapy, in which the extent of ablation is rather unpredictable, MDA enables precise closure of target veins [37-39]. Without tumescence the distance between the tip of the needle inserted to the subfascial part of perforator and the deep veins is approximately 3-4 $\mathrm{mm}$, after tumescence this distance increases to $10-15 \mathrm{~mm}$. In addition, tumescence lowers local temperature of tissues, separates other anatomical structures from the ablated blood vessel, and expels blood from the lumen of target perforator. The latter phenomenon protects from formation of thrombus inside the ablated perforator, which is of particular importance in cases with wide and short perforating veins and also those connected to subfascial venous malformations. Thus, MDA together with protective tumescence enables safe and accurate ablation of incompetent veins, with no associated risk of extravascular injuries. In contrast to classic surgery with subfascial ligation of perforators [4042], endovascular ablation does not result in subfascial scarring, thus making possible another future procedure in this area.

\section{CONCLUSIONS}

Monopolar diathermy with the use of protective tumescence enables minimally invasive, effective, and precise ablation of incompetent perforators. This method is also safe and is not associated with injuries to adjacent anatomical structures or thromboembolic complications.

The authors declare no conflict of interest.

\section{References}

1. Sukhovatykh B.S., Sukhovatykh M.B. Perforating veins insufficiency in patients with varicose disease. Khirurgiia (Mosk) 2015; 5: 14-18.

2. Guch A.A., Chernukha L.M., Smorzhevskiy V.I., Bobrova A.O. Role of perforating veins in occurrence of varicose disease and its recurrences after surgical interventions. Klin Khir 2015; 3: 32-35.

3. Pesta W., Kurpiewski W., Kowalczyk M., SzynkarczukR., Luba M., Zurada A., Grabysa R. The place of subfascial endoscopic perforator vein surgery (SEPS) in advanced chronic venous insufficiency treatment. Wideochir Inne Tech Maloinwazyjne 2011; 6: 181-189.

4. Meissner M.H. Lower extremity venous anatomy. Semin Intervent Radiol 2005; 22: 147-156.

5. Bootun R., Davies A.H. Long-term follow-up for different varicose vein therapies: is surgery still the best? Phlebology 2016; 31 (1 Suppl): 125-129.

6. Health Quality Ontario. Endovascular radiofrequency ablation for varicose veins: an evidence-based analysis. Ont Health Technol Assess Ser 2011; 11: 1-93.

7. Van den Bremer J., Moll F.L. Historical overview of varicose vein surgery. Ann Vasc Surg 2010; 24: 426-432.

8. Goode S.D., Chowdhury A., Crockett M., Beech A., Simpson R., Richards T., Braithwaite B.D. Laser and radiofrequency ablation study (LARA study): a randomised study comparing radiofrequency ablation and endovenous laser ablation $(810 \mathrm{~nm})$. Eur J Vasc Endovasc Surg 2010; 40: 246-253.

9. Nishibe T., Mnishibe M., Suzuki S., Takahashi S., Toguchi K., Kamiya K., Iwahashi T., Ogino H. Venous hemodynamic improvement after endovenous radiofrequency ablation of saphenous varicose veins. Int Angiol 2017; 36: 64-68.

10. Pannier F., Rabe E. The relevance of the natural history of varicose veins and refunded care. Phlebology 2012; 27 Suppl 1: 23-26.

11. Caggiati A., Rosi C., Casini A., Cirenza M., Petrozza V., Acconcia M.C., Zamboni P. Skin iron deposition characterises lipodermatosclerosis and leg ulcer. Eur J Vasc Endovasc Surg 2010; 40: 777-782.

12. Caggiati A., Franceschini M., Heyn R., Rosi C. Skin erythrodiapedesis during chronic venous disorders. J Vasc Surg 2011; 53 : 1649-153.

13. Bogaczewicz J., Dudek W., Wroński J., Chodorowska G., Przywara S., Krasowska D., Zubilewicz T. The role of matrix metalloproteinases in venous leg ulcers development. Pol Merkur Lekarski 2005; 19: 686-692.

14. Segiet O.A., Brzozowa-Zasada M., Piecuch A., Dudek D., Reichman-Warmusz E., Wojnicz R. Biomolecular mechanisms in varicose veins development. Ann Vasc Surg 2015; 29: 377-384.

15. Karch A., Kasperczyk J. Somatic risk factors for chronic venous insufficiency in women - preliminary report. Wiad Lek 2002; 55 (Suppl 1): 212-216.

16. Jawień A. The influence of environmental factors in chronic venous insufficiency. Angiology. 2003; 54 (Suppl 1): S19-31. 
17. Reček Č. The haemodynamic role of calf perforators. Phlebol Rev 2014; 22: 45-48.

18. Simka M. Lower leg perforators in human health and disease. Phlebol Rev 2014; 22: 49.

19. Sukovatykh B.S., Sukovatykh M.B. Mechanisms of development of incompetent perforating veins in patients with varicose vein disease of lower limbs. Vestn Khir Im I I Grek 2015; 174: 15-19.

20. Obermayer A., Göstl K., Walli G., Benesch T. Chronic venous leg ulcers benefit from surgery: long-term results from 173 legs. J Vasc Surg 2006; 44: 572-579.

21. van Gent W.B., Catarinella F.S., Lam Y.L., Nieman F.H., Toonder I.M., van der Ham A.C., Wittens C.H. Conservative versus surgical treatment of venous leg ulcers: 10-year follow up of a randomized, multicenter trial. Phlebology 2015; 30 (1 Suppl): 35-41.

22. Gloviczki P., Comerota A.J., Dalsing M.C., Eklof B.G., Gillespie D.L., Gloviczki M.L., Lohr J.M., McLafferty R.B., Meissner M.H., Murad M.H., Padberg F.T., Pappas P.J., Passman M.A., Raffetto J.D., Vasquez M.A., Wakefield T.W.; Society for Vascular Surgery; American Venous Forum. The care of patients with varicose veins and associated chronic venous diseases: clinical practice guidelines of the Society for Vascular Surgery and the American Venous Forum. J Vasc Surg 2011; 53 (5 Suppl): 2S-48S.

23. Urbanek T., Kuczmik W., Kostyra J., Ziaja D., Drążkiewicz T., Kucharzewski M., Ludyga T. Podpowięziowe endoskopowe przecinanie perforatorów $\mathrm{w}$ leczeniu powikłań przewlekłej niewydolności żylnej - doświadczenia własne. Pol Surg 2004; 6: 195-201.

24. Ciostek P., Myrcha P., Noszczyk W. Ten years experience with subfascial endoscopic perforator vein surgery. Ann Vasc Surg 2002; 16: 480-487.

25. Drążkiewicz T., Błaszczyński M., Zaniewski M., Długaj M., Gniadek J., Majewski E., Urbanek T., Ziaja K. Leczenie zespołu pozakrzepowego powikłanego nie gojącym się owrzodzeniem w świetle własnych doświadczeń. Phlebol Rev 1997; 5 (1 Suppl): 52-55.

26. Chudek J., Mikosiński J., Kobielski A., Hering A., Aleksiejew-Kleszczyński T., Umiński J., Zubilewicz T., Kobusiewicz W. Iłżecki M., Wojtak A., Stec J., Urbanek T. Patients's satisfaction with therapy methods of advanced chronic venous disease. Int Angiol 2016; 35: 98-107.

27. Berszakiewicz A., Stanek A., Sieroń A. Recent methods of evaluation of quality of life in patients with chronic venous disease. Wiad Lek 2014; 67: 499-504.

28. Franks P.J., Barker J., Collier M., Gethin G., Haesler E., Jawień A., Laeuchli S., Mosti G., Probst S., Weller C. Management of patients with venous leg ulcers: challenges and current best practice. J Wound Care 2016; 25 (Suppl 6): S1-S67.

29. Ozsvath K., Hager E., Harlander-Locke M., Masuda E., Elias S., Dillavou E.D. Current techniques to treat pathologic perforator veins. J Vasc Surg Venous Lymphat Disord 2017; 5: 293-296.

30. Dumantepe M., Tarhan A., Yurdakul I., Ozler A. Endovenous laser ablation of incompetent perforating veins with $1470 \mathrm{~nm}$, $400 \mu \mathrm{m}$ radial fiber. Photomed Laser Surg 2012; 30: 672-677.

31. Peden E., Lumsden A. Radiofrequency ablation of incompetent perforator veins. Perspect Vasc Surg Endovasc Ther 2007; 19: 73-77.

32. Toonder I.M., Lam Y.L., Lawson J., Wittens C.H. Cyanoacrylate adhesive perforator embolization (CAPE) of incompetent per- forating veins of the leg, a feasibility study. Phlebology 2014; 29 (1 Suppl): 49-54.

33. Marsh P., Price B.A., Holdstock J.M., Whiteley M.S. One-year outcomes of radiofrequency ablation of incompetent perforator veins using the radiofrequency stylet device. Phlebology 2010; 25: 79-84.

34. Hager E.S., Washington C., Steinmetz A., Wu T., Singh M., Dillavou E. Factors that influence perforator vein closure rates using radiofrequency ablation, laser ablation, or foam sclerotherapy. J Vasc Surg Venous Lymphat Disord 2016; 4: 51-56.

35. García Carriazo M., Gómez de las Heras C., Mármol Vázquez P., Ramos Solís M.F. Doppler ultrasound study and venous mapping in chronic venous insufficiency. Radiologia 2016; 58: 7-15.

36. Zygmunt J. Jr. What is new in duplex scanning of the venous system? Perspect Vasc. Surg Endovasc Ther 2009; 21: 94-104.

37. Kulkarni S.R., Slim F.J., Emerson L.G., Davies C., Bulbulia R.A., Whyman M.R., Poskitt K.R. Effect of foam sclerotherapy on healing and long-term recurrence in chronic venous leg ulcers. Phlebology 2013; 28: 140-146.

38. Aronniemi J., Castrén E., Lappalainen K., Vuola P., Salminen P., Pitkäranta A., Pekkola J. Sclerotherapy complications of peripheral venous malformations. Phlebology 2015; doi: $10.1177 / 0268355515613740$.

39. Castrén E., Aronniemi J., Klockars T., Pekkola J., Lappalainen K., Vuola P., Salminen P., Pitkäranta A. Complications of sclerotherapy for 75 head and neck venous malformations. Eur Arch Otorhinolaryngol 2016; 273: 1027-1036.

40. Ioannou C.V., Giannoukas A.D., Kostas T., Kafetzakis A., Liamis A., Touloupakis E., Tsetis D., Katsamouris N. Patterns of venous reflux in limbs with venous ulcers. Implications for treatment. Int Angiol 2003; 22: 182-187.

41. Iafrati M.D. Subfascial endoscopic perforator vein surgery. Semin Cutan Med Surg 2005; 24: 209-215.

42. Kalra M., Gloviczki P. Subfascial endoscopic perforator vein surgery: who benefits? Semin Vasc Surg 2002; 15: 39-49. 